\title{
The Theoretical Linkages between the Shariah Supervisory Board (SSB) and Stakeholder Theory in the Islamic Financial Institutes: An Empirical Review
}

\author{
K. M. Anwarul Islam \\ $\mathrm{PhD}$ Candidate \\ Faculty of Business and Accountancy \\ University of Selangor, Malaysia \\ E-mail:ai4I9bankingdu@gmail.com \\ Abul Bashar Bhuiyan PhD \\ Associate Professor \\ Faculty of Business and Accountancy \\ University of Selangor, Malaysia \\ E-mail:bashariuk@gmail.com
}

\begin{abstract}
As part the Corporate Governance, the Shariah Supervisory Board has a significant role in the Islamic Financial Institutes for ensuring its conformity with the Shariah standards. In general, the Corporate governance should be played essential roles to design and promote principles of fairness, accountability, and transparency to meet of all the stakeholder's rights such as shareholders, the workers, the depositors, and the customers, etc. however, there are still struggling for convincing arguments to justify stakeholders' participation in governance in the traditional conventional systems rather, the Stakeholder theory has become one of the most important developments in the field of business ethics, which is widely regarded as being a key element in Islamic banking, making it of extreme relevance in Islam's principles of property rights, commitment. Therefore, this study aims to justify the theoretical linkages or relationship between the role of the Shariah Supervisory Board of Islamic banking and stakeholders' model from the existing empirical literature review. The summary of empirical review findings revealed that the stakeholder concept in a way that overcomes many of the existing limitations and provides a different understanding of the identity and meaning of Islamic banking, specifically in terms of its relationship to stakeholder groups, such as Islamic banks are a connected body, they should have control over the external environment and should implement hierarchies. Moreover, the developed a conceptual framework to do empirical research by applying real data to test the significance of the above relationships for further policy explorations.
\end{abstract}

Keywords: Stakeholder Theory, Shariah Supervisory Board, IFSB.

\section{Introduction}

The Sharia law, which was established around I,400 years ago, regulates Islamic banking (Islam, 20I7b). In the last few years, Islamic finance has had experienced enormous growth (Islam, 20I4). Islamic finance is a growing trend that has arisen to meet the financial needs of the devoted Muslims who comply with the ban on Riba (usury) - I,6 billion Muslims around the world (Islam, 2016c). In Muslim majority and minority nations, this pattern has been observed (Grassa, 2013). An important factor leading to this is to comply, through Islamic banking, with Islamic law (Shari'ah afterward) (Erol \& El-Bdour, I989; Metswa \& Al-Mossawi, I998; Naser et al., I999; Bley \& Kuehn, 2004; Alnasser \& Muhammed, 2012) due to their conformity to customers' religious orientations. Islamic finance institutions are therefore resorting to Shari'ah scholars forming SSBs to ensure that their services comply with the rules of the Shari'ah. The ultimate task of the SSBs consists of ensuring that Islamic financial institutions offer services and resources under the Shari'ah laws, a prerequisite for all Islamic financial institutions (IFSB 2006; Alnasser \& Muhamed 2012; Grassa 2013).

Here, the practice of Islamic finance, in general, is worth mentioning, and all countries, particularly of the respective SSBs, the reliance upon debt similar instruments that were seen as simply a replication of traditional financial instruments was severely criticized (Grassa, 2013; Echchabi \& Aziz, 2014). These problems will threaten and hinder the prospects of the 
industry and successful growth (IFSB, 2006). It is therefore important to explain the SSBs and their activities. In this report, the aspects discussed include the structure of the SSB and the presence and use of external auditors or experts of the Shari'ah; the process of SSB decision-making; the status and interpretation of various Madzhab and standards; reviewing and selection of samples of operations; potential methods to harmonize the Islamic financial industry between countries, etc.

\section{Theory of Stakeholder}

The Islamic opinion on the theory of stakeholders offers thorough verification of stakeholders ' capacities and their obligations to comply with the relevant guidelines, as well as their various stakeholders. Similar rules were accepted by Iqbal \& Mirakhor (2004) in the Islamic concepts of ownership and agreements. Therefore, a business is responsible for protecting the implied inviolability agreements by protecting all's rights concerned parties including customers, investors, sellers, workers, and local communities Sharia law which promotes social order and economic development is granted and maintained. Within Islamic financial institutions, there are several players and investors. This raises the question of whether the interests of all shareholders are to be protected (Islam, 2017 a). Changing corporate scenarios have focused on firm stakeholders on corporate governance theorization (Islam, 2016a).

The theory of the shareholders says all parties that influence the performance of the company are important for the company's success. Such parties might be suppliers, business associations, consumers, etc. Figure I shows a company's possible investors, and the firm is an Islamic bank in this analysis and its needs should be considered, according to Donaldson (I995), to achieve an optimal outcome.

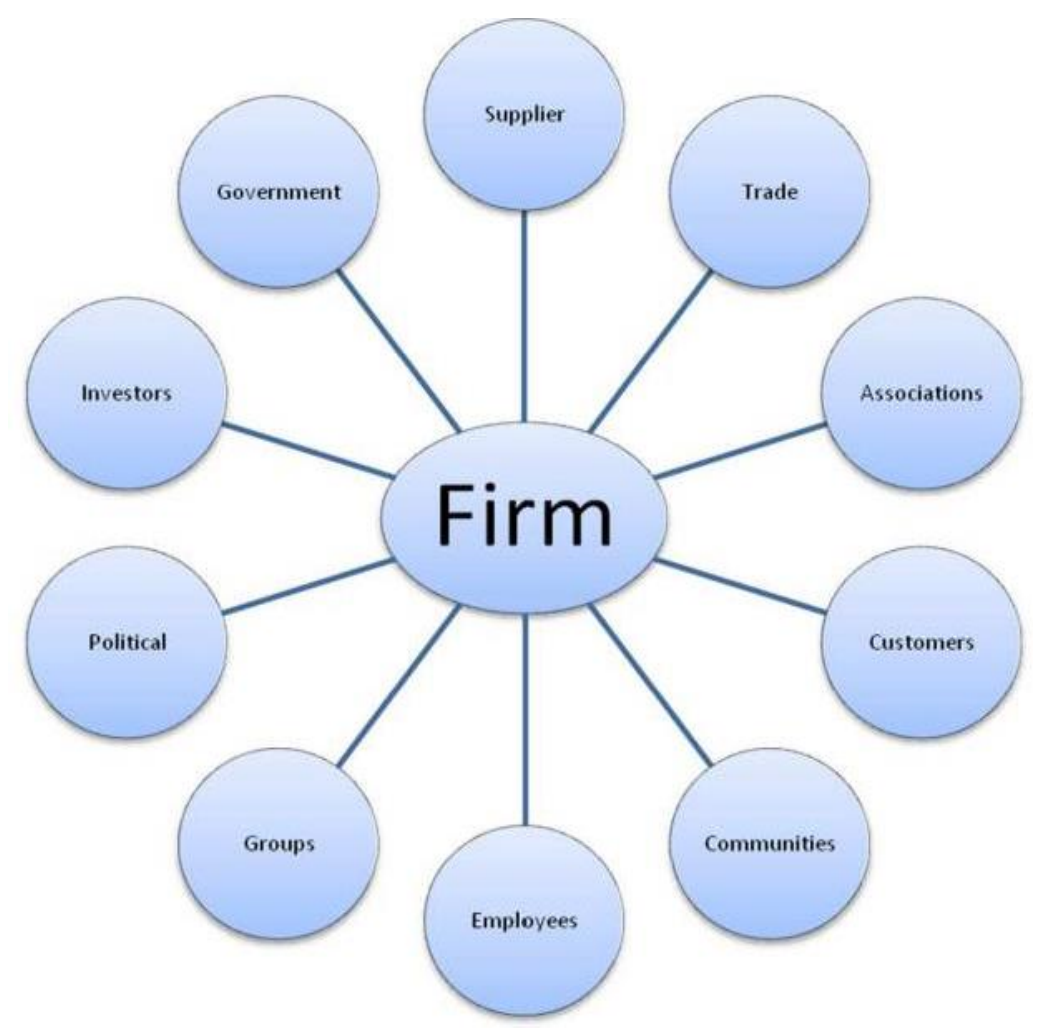

Figure I. The Stakeholder Model

Adapted from "The Stakeholder Organization Theory: Principles, Evidence, and Implications."

Islamic corporate governance debates reflect the gaps between Western and Islamic corporate governance (Hasan, 2009). Banking scientists called for a broader Islamic context, which would take into account both legislative and ethical governance aspects (Abdul Rahman, 1998).

In the Islamic banking sense, a shariah supervisory board is important, because it must be licensed for transactions and activities of Muslim banks. One of the key players in Islamic banking is the Shariah Supervisory Board. It offers an opportunity to understand, through stakeholder theory, the relationship between corporate governance and banking performance. 
There are increasingly examples of stakeholder theory in countries in which workers have a clear influence on their organizations ' activities in Germany, Sweden, and Japan, for example. Such principles strengthen the ability to participate in the present and future projects of all people involved in this organization. In short, the concept of the stakeholder is best suited for the current study. Changing corporate sector dynamics also forced business investors to concentrate on corporate governance (Islam, 2016b).

According to the Islamic stakeholder template, four key players are chosen for their financial performance as influencing a bank. These were the first management, that is to say, the duality of the positions and autonomy of the CEO, the size of the Board of Directors and the three other factors identified in the board (independence from the Board, frequency of the Board meetings, Board members ' experience and the size of the Board). The Board of Directors was responsible for this twofold.

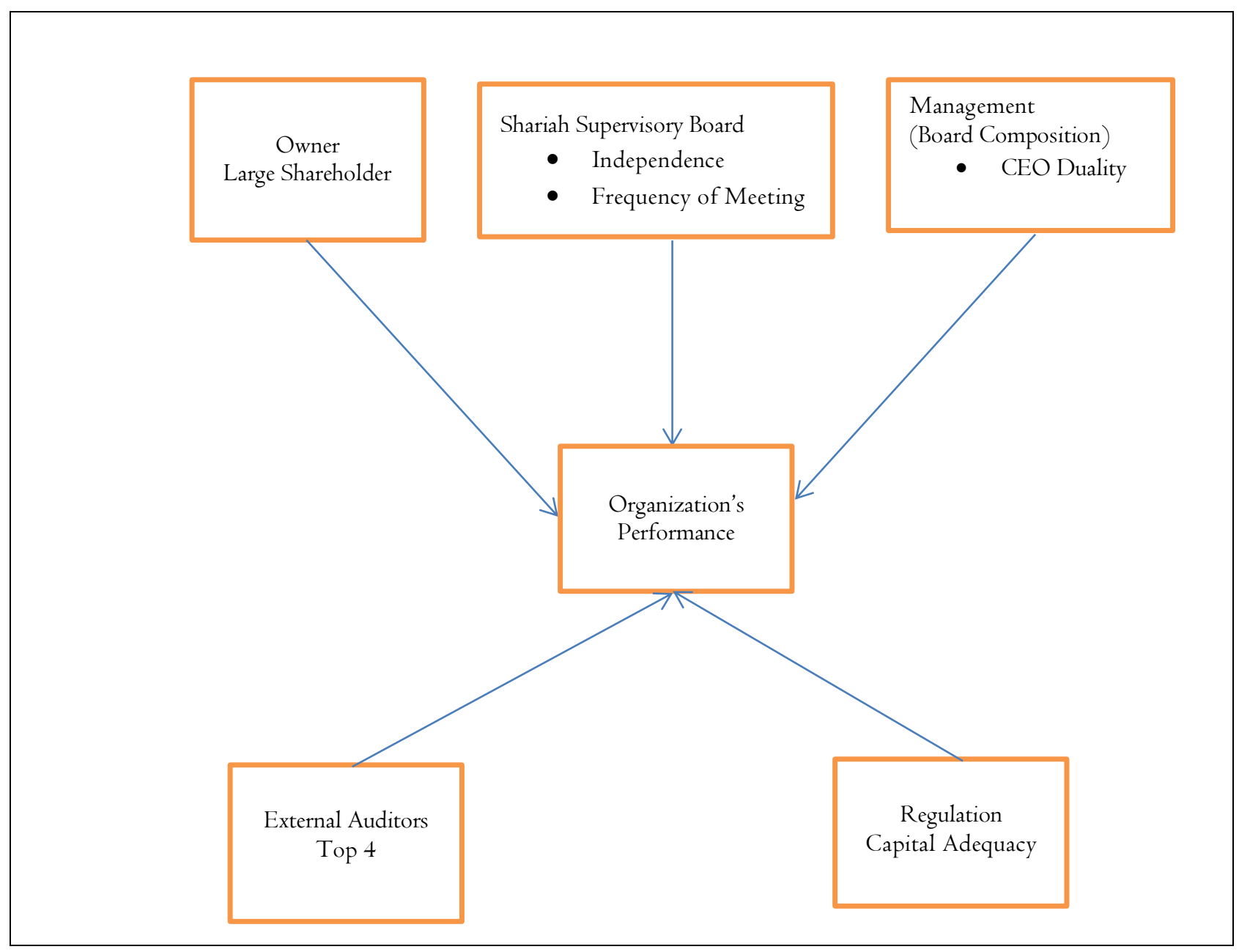

Figure 2. Conceptual, evidence and impact factors that influence the performance of Islamic banks adapted to the "Corporation Stakeholder Theory" (p.69), by Donaldson (I995), Academy of Management Review

With the emergence of Islamic Banking, the concept of religious regulation was born to guarantee that investors and other groups trusted Islamic Shariah banks. Shariah's supervisory board replaces the traditional board of directors in Islamic banks (Ghayad, 2008) Investors are usually appointed to supervise the operations of the Islamic Bank by the Management Board. The Board of Directors has been set up to ensure that the purposes and practices of an Islamic bank are harmonized and high management effectively implemented. The Managing Board shall define the corporate strategy, appoint senior managers, and provide accurate data and establishes effective controls for the oversight of the Bank, including audit processes.

Throughout Islamic banks, the system of internal controls consists of policies and procedures to ensure that the Bank is capable of achieving its goals and objectives (Beasley, 1996). The Board of Directors has an important role to play in overseeing the senior management level as the Islamic Bank operates. The board has to control and supervise the assets and 
activities of the bank (Grais \& Pellegrini, 2006). The Board, therefore, is considered to be a collective team of people whose main purpose is to protect the interests of the investors (Norita \& Shamsul, 2004), who have fiduciary responsibility to run and manage an Islamic bank.

An appropriate reason for discussion might be defined as other variables are excluded that could play a significant role in evaluating the pertinence of an independent variable-dependent relationship existence. One reason may be that the other variables suggest a thorough understanding of the shariah principles, which may lead to strategies aimed at minimizing agency involvement, which is outside the reach of the current study and which may provide enough room for further analysis, and this could lead to a dispute with Sharia Islamic values (Safieddine, 2009). Additional research can also be done to determine whether companies that choose to improve corporate governance are benefiting from problems that reflect the value of the constitutional minority rights interests during other crises or stable periods (Mitton, 2002).

\section{The Theoretical Linkages between Stakeholder Theory and Shariah Supervisory Board}

Freeman (1984) argues that businesses are part of a broader spectrum of entities within a social system where they operate and that, therefore, they are responsible for their well-being and welfare (Donaldson \& Prestton I995; Rowley I997). (Donaldson and Preston, 1995) This theory refers to the relationship between managers and stakeholders and states that this relationship is more important than just the relationship between the owner and manager (Elena, 20I2). This is because the stakeholder and the company have a mutual influence and both can impact each other through various means and methods (Freeman, I994). This is the result of this importance. Guthrie et al (2006) claimed that: In this respect:

According to the Stakeholder Theory, management of an organization is required to conduct activities which its stakeholders consider important and report to stakeholders on those activities. Stakeholder theory stresses the transparency of companies over and above simple economic or financial performance.

It can be inferred from the discussion above that two key points were discussed in consideration of SSB theory of stakeholders including:

- The company's duty is trustworthy. Therefore, not only the owners but also all stakeholders must be held responsible.

- All stakeholders must maintain the right to take part in the decision-making process that might impact them. This requires transparency and reporting of the company to the parties concerned.

A criticized stakeholder theory was that the company was monetized (Jensen, 200I). It deviated from its objectives with a focus on stakeholders (Ansoff, 1987) and created competitive problems through the flow of information towards other working contexts (Yusoff \& Alhaji, 2012). In reaction to these claims, Roberts (I992) proposed that companies prioritize and formulate strategies for their shareholders based on their value, energy, and dependency.

The Stakeholder theory and SSB are seen as an important tool for IFIs in fulfilling this accountability, especially with regard to Shariah questions (Grais \& Pellegrini, 2006), in line with the principles of stakeholder theory which call for accountability for stakeholders. A number of studies have suggested that Shariah compatibility information and transparency are increasingly required for different stakeholders in society including Muslim Ummah (Akhtar, 2006; Grais \& Pellegrini, 2006; Abu-Tapanjeh, 2009; Bhatti \& Bhathti, 2009; Kasim et al, 2013). Studies in SSB have shown that stakeholder theory is relevant to this particular field (Iqbal \& Bhatti, 2010.). Asutay, 2007 said that one of the means to fill the gap between Islamic finance ambitions and Islamic banks, 2009; Hasan, 2009; Bhatti \& Bhatti, 2010) and (Sounded in the SSB study) The findings show that Islamic banking success depends heavily on its connections with Islamic society. The Hasan (2009) notes that the SSB and the stakeholder theory are distinguished by four main characteristics, epistemic, organizational goals, management and management characteristics, and finally the ownership structure of the asset. In Islamic epistemology, the concept of Tawhid means that God (SWT) makes everything, and the ultimate responsibility has to be for him (Hasan, 2009). In addition, Maqasid al-Shariah is the goal of Islamic companies that should protect everyone's interests and well-being (Dusuki \& Abdullah 2007). 


\section{Conceptual Framework}

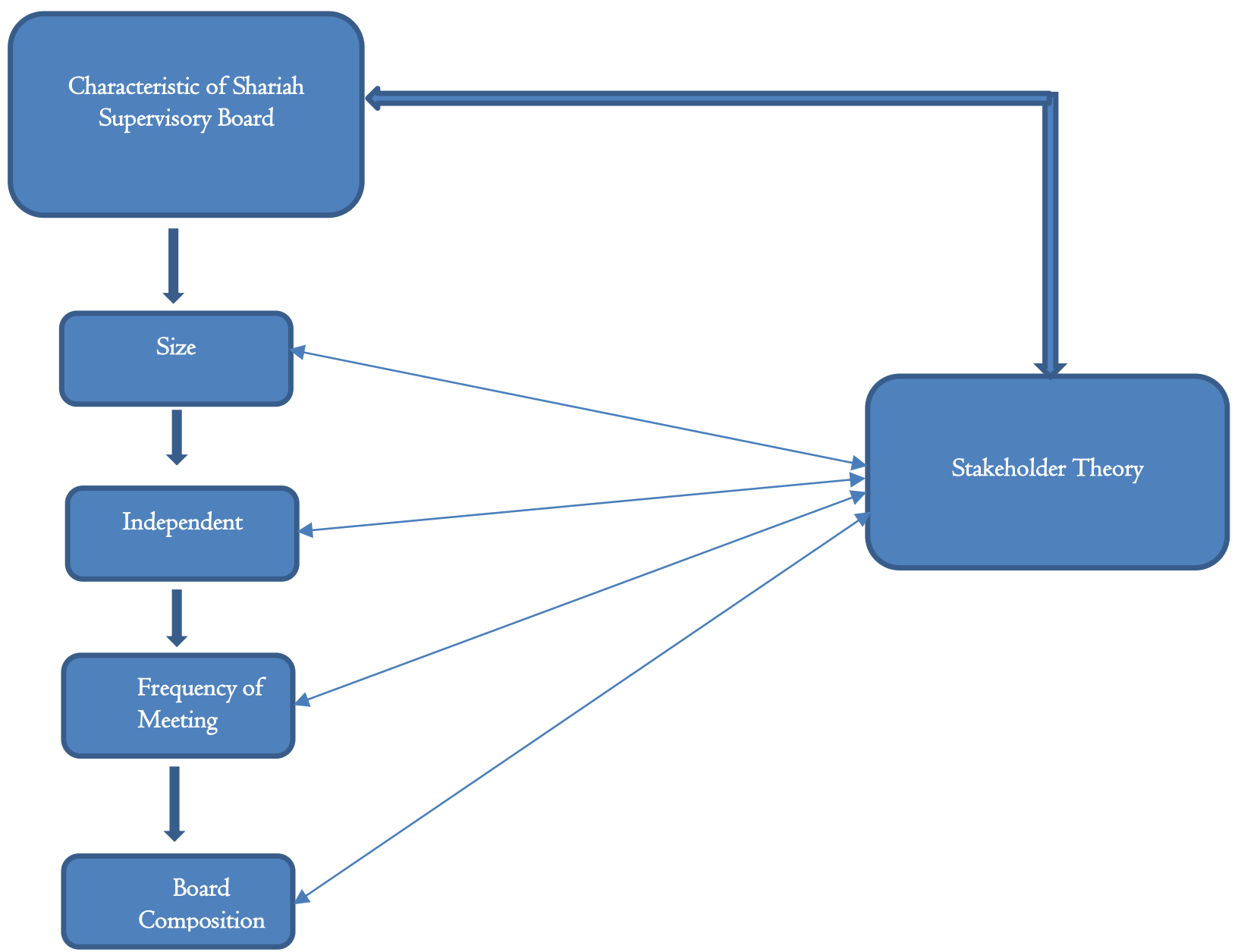

Figure 3. Conceptual Framework of Shariah Supervisory Board (SSB) and Stakeholder Theory in the Islamic Financial Institutes

\section{Conclusion}

As the aim of this study is to justify the linkages or theoretical relationship between the role of the Shariah Supervisory Board (SSB) of the Islamic banking and stakeholders' model from the existing empirical literature review. The findings of the study explored that the Shariah Supervisory Board has significant role on the Islamic Financial Institutes for ensuring of its conformity with the Shariah standards by implementing of essential roles to design and promote principles of fairness, accountability, and transparency to meet of all the stakeholder's rights such as shareholders, the workers, the depositors, and the customers, etc. on the other hand, the stakeholders' participation in governance in the traditional conventional systems are still in drift from their mission rather, the Stakeholder theory has become one of the most important developments in the field of business ethics, which is widely regarded as being a key element in Islamic banking, making it of extreme relevance in Islam's principles of property rights, commitment. Therefore, the major summary of review findings revealed that the stakeholder concept in a way that overcomes many of the existing limitations and provides a different understanding of the identity and meaning of Islamic banking, specifically in terms of its relationship to stakeholder groups, such as Islamic banks are a connected body, they should have control over the external environment and should implement hierarchies. However, it has also noticed that the SSB functions are regulated and directed by the central banks of all countries in the supervision of Islamic banks, which are responsible for ensuring that the accomplishment of banking operations does not infringe or ignore Islamic values. Moreover, 
the developed a conceptual framework to do empirical research by applying of real data to test the significance of the above relationships for further policy explorations.

\section{References}

Abdullah Saif Alnasser, S., \& Muhammed, J. (20I2). Introduction to corporate governance from Islamic perspective. Humanomics, 28(3), 220-231.

Abdul Rahman, A. R. (1998). Issues in corporate accountability and governance: An Islamic perspective. American Journal of Islamic Social Sciences, I5, 55-70.

Akhtar, S. (2006). Syariah Compliant Corporate Governance. In: Nasser Saidi, Keynote Address by the Governor of the State Bank of Pakistan at the Annual Corporate Governance Conference, Dubai, United Arab Emirates, November. Hawkamah Institute for Corporate Governance.

Abu-Tapanjeh, A.M. (2009). Corporate governance from the Islamic perspective: A comparative analysis with OECD principles. Critical Perspectives on Accounting, 20(5), 556-567.

Ansoff, H.I. (1987). The emerging paradigm of strategic behavior. Strategic Management Journal, 8(6), 50I-5I5.

Azid, T., Asutay, M. \& Burki, U. (2007). Theory of the firm, management and stakeholders: An Islamic perspective. Islamic Economic Studies, I5(I), I-30.

Asutay, M. (2007). Conceptualisation of the second-best solution in overcoming the social failure of Islamic banking and finance: Examining the overpowering of homoislamicus by homoeconomicus. International Journal of Economics, Management and Accounting, 15(2), I67-I95.

Bhatti, M. \& Bhatti, M.I. (2010). Toward understanding Islamic corporate governance issues in Islamic finance. Asian Politics \& Policy, 2(I), 25-38.

Bhatti, M. and Bhatti, I. (2009). Development in legal issues of corporate governance in Islamic finance. Journal of Economic and Administrative Sciences, 25(I), 67-9I.

Bley, J., \& Kuehn, K. (2004). Conventional versus Islamic finance: student knowledge and perception in the United Arab Emirates. International journal of Islamic financial services, 5(4), I7-30.

Beasley, M. S. (1996). An empirical analysis of the relation between the board of director composition and financial statement fraud. Accounting Review, 443- 465.

Chapra, M.U. (2007). Islam and Economic Development: A Strategy for Development with Justice and Stability. New Delhi, India: Adam Publishers.

Dusuki, A.W. \& Abdullah, N.I. (2007). Maqasid al-shari'ah, maslahah and corporate social responsibility. The American Journal of Islamic Social Sciences, 24(I), 25-45.

Donaldson, T., \& Preston, L. E. (I995). The stakeholder theory of the corporation: Concepts, evidence, and implications. Academy of management Review, 20(I), 65-9I.

Erol, C., \& El-Bdour, R. (I989). Attitudes, behaviour, and patronage factors of bank customers towards Islamic banks. International Journal of Bank Marketing, 7(6), 3I-37.

Echchabi, A., \& Aziz, H. A. (2014). Shari’ah issues in Islamic banking: a qualitative survey in Malaysia. Qualitative Research in Financial Markets.

Elena, G.C. (2012). Theoretical framework for corporate governance. Ovidius University Annals, Economic Sciences Series, I2(I), 493-498.

Freeman, R.E. (1994). The politics of stakeholder theory. Bus Ethics Quart, 4(4), 409-42I.

Freeman, R.E. (1984). Strategic Management: A Stakeholder Approach. Boston, MA: Pitman.

Grassa, R. (2013). Shariah supervisory system in Islamic financial institutions: New issues and challenges: A comparative analysis between Southeast Asia models and GCC models, Humanomics, 29(4), 333-348.

Ghayad, R. (2008). Corporate governance and the global performance of Islamic banks, Humanomics, $24(3), 207-216$.

Guthrie, J., Petty, R. \& Ricceri, F. (2006). The voluntary reporting of intellectual capital: Comparing evidence from Hong Kong and Australia. Journal of Intellectual Capital, 7(2), 254-27I.

Grais, W., \& Pellegrini, M. (2006). Corporate governance in institutions offering Islamic financial services: issues and options. The World Bank.

Hasan, Z. (2009). Corporate governance: Western and Islamic perspectives. International Review of Business Research Papers, $5(\mathrm{I}), 277-293$

IFSB. (2006). Guiding Principles on Corporate Governance for Institutions Offering Only Islamic Financial Services (excluding Islamic insurance (takaful) institutions and Islamic mutual funds),IFSB,Kuala Lumpur.

Islam, K. M. A, Alam, I., \& Hossain, S. A. (2014). Examination of profitability between Islamic banks and conventional banks in Bangladesh: A comparative study. Research in Business and Management, I(I), 78-89. Retrieved from http://www.macrothink.org/journal/index.php/rbm/article/view/4894 
Islam, K. M. A. (2016a). Corporate Governance: Conjecture and Modernism, Indian Journal of Science, $23(86), 798-817$. Retrieved from https://discoveryjournals.org/science/current_issue/2016/index.htm

Islam, K. M. A. (2016b). History and Role of Islamic Finance, International Journal: Discovery, 52(252), $2410-2418$. Retrieved from https://discoveryjournals.org/discovery/current_issue/v52/n252/index.htm

Islam, K. M. A. (2016c). Corporate Governance of Banking Institutions: Bangladesh Perspective, ISBN 978-3-659-890055,LAP LAMBERT Academic Publishing, Germany.

Islam, K. M. A., \& Barghouthi, O. A. (2017a). Corporate Governance: An Islamic Institution Perspective. International Journal of Islamic Banking and Finance Research,I(I), 29-32. Retrieved from http://www.cribfb.com/journal/index.php/ijibfr/article/view/36

Islam, K. M. A. (2017b). Finance: An Islamic Perspective. International Journal of Islamic Banking and Finance Research, I(I), I-5. Retrieved from http://www.cribfb.com/journal/index.php/ijibfr/article/view/32

Iqbal, Z. \& Mirakhor, A. (2004). Stakeholders model of governance in islamic economic system. Islamic Economic Studies, II (2), 43-64.

Kasim, N., Htay, S. N. N., \& Salman, S. A. (2013). Shariah governance for Islamic capital market: A step forward. International Journal of Education and Research, I(6), I-I4.

Metawa, S. A., \& Almossawi, M. (1998). Banking behavior of Islamic bank customers: perspectives and implications. International journal of bank marketing, I6(7), 299-313.

Mitton, T. (2002). A cross-firm analysis of the impact of corporate governance on the East Asian financial crisis. Journal of financial economics, 64(2), 215-24I.

Norita, M. N., \& Shamsul Nahar, A. (2004). Voluntary disclosure and corporate governance among financially distressed firms in Malaysia. The Electronic Joumal of the Accounting Standards Interest Group of AFAANZ,3(I).

Naser, K., Jamal, A., \& Al-Khatib, K. (I999). Islamic banking: a study of customer satisfaction and preferences in Jordan. International journal of bank marketing, I7(3), I35-I5I.

Rowley, T.J. (1997). Moving beyond dyadic ties: A network theory of stakeholder influences. Academy of Management Review 22(4), 887-910.

Roberts, R.W. (1992). Determinants of corporate social responsibility disclosure: an application of stakeholder theory. Accounting, Organizations and Society I7(6), 595-6I2.

Safieddine, A. (2009). Islamic financial institutions and corporate governance: New insights for agency theory. Corporate Governance: An International Review, I7(2), I42-I58.

Yusoff, W.F.W. and Alhaji, I.A. (2012). Insight of corporate governance theories. Journal of Business and management I(I), 52-6.

Copyrights

Copyright for this article is retained by the author(s), with first publication rights granted to the journal. This is an open-access article distributed under the terms and conditions of the Creative Commons Attribution license (http://creativecommons.org/licenses/by/4.0/). 